\title{
Re-enterprising the unplanned urban areas of Greater Cairo - a social innovation perspective
}

\author{
Katerina Nicolopoulou \\ Hunter Centre for Entrepreneurship, University of Strathclyde, Glasgow, UK \\ Ashraf M. Salama \\ Department of Architecture, University of Strathclyde, Glasgow, UK \\ Sahar Attia \\ Department of Architecture, Faculty of Engineering, \\ Cairo University, Cairo, Egypt \\ Christine Samy \\ Hunter Centre for Entrepreneurship, University of Strathclyde, Glasgow, UK \\ Donagh Horgan \\ Department of Architecture, University of Strathclyde, Glasgow, UK \\ Heba Allah Essam E. Khalil \\ Department of Architecture, Cairo University, Cairo, Egypt, and \\ Asser Bakhaty \\ Department of Architecture, University of Strathclyde, Glasgow, UK
}

\begin{abstract}
Purpose - This study aims to develop an innovative and comprehensive framework to address water related challenges faced by communities located in urban settlements in the area of Greater Cairo. It is commonly accepted that such global challenges that border issues of resilience, community development, social equity and inclusive growth, call for a collaboration of disciplines. Such collaboration allows for the identification of synergies in ways that can enlighten and enrich the space of potential solutions and create pathways towards robust solutions.

Design/methodology/approach - Theresearch process has been participatory, and it involved, apart from site interviews, engagement via a photographic exhibition, during an outreach and engagement event, of the researched sites in one of the academic institutions of the authors. A total of 12 women were interviewed and the expert's workshop was attended by 12 experts.

Findings - Social innovation can promote agile processes to prototyping services, involving multiple sectors and stakeholders through open ecosystems. For urban settlements undergoing rapid expansion, social innovation can help communities and governments to build resilience in the face of resource gaps often making use of advancements in technology and improvements from other disciplines (Horgan and Dimitrijevic, 2019). For the unplanned urban areas around Greater Cairo, input from different knowledge areas can offer valuable contributions; in terms of the project and the study that we report on in this paper, the contributing areas included architecture and urban planning, as well as women led entrepreneurship targeting economic growth, social and community impacts.

Originality/value - In this paper, we demonstrate the significance of a transdisciplinary framework based on social innovation, for the study of women-led entrepreneurship as a response to water-based challenges within an urban settlement. The creation of such a framework can be a significant contribution to conceptualise, examine and respond to "wicked challenges" of urban sustainability. This paper also believes that the readership of the journal will be subsequently benefitting from another way to conceptualise the interplay of theoretical perspectives at the level of organisations and the individual to support the inquiry into such challenges.
\end{abstract}


Keywords Entrepreneurship, Women entrepreneurs, Water, Social innovation, Socially and culturally sustainable architecture and urban design, Unplanned urban areas Paper type Research paper

\section{Re-enterprising the unplanned urban areas of Greater Cairo- a social innovation perspective}

\section{Introduction}

This research aims to develop an innovative and comprehensive framework in order to address water-related challenges faced by communities located in urban settlements in the area of Greater Cairo. As Fabiola Giannoti (2018, p.127), the Director- General of CERN argued 'Today society faces many challenges: climate change/energy supply/food security and public health/to name a few. Collaborative science is an inescapable part of the solution to them' It is commonly accepted that such global challenges that border issues of resilience, community development, social equity as well as inclusive growth, call for a collaboration of disciplines. Such collaboration allows for the identification of synergies in ways that can enlighten and enrich the space of potential solutions, and create pathways towards robust solutions. The premise adopted in this research is that in addressing tangible real-world problems, no longer can individual disciplines have strong claims over their own direction and areas of knowledge production in isolation from what is happening in other disciplines or fields of inquiry. Solving the intractable problems that emerge within spaces such as rapidly developing urban settlements requires interdisciplinary, transdisciplinary and even post disciplinary approaches that bring together separate fields of knowledge, while crossing their boundaries (Salama, 2011).

The aim of the study is to develop a framework for placed-based social innovation in the context of Greater Cairo, bringing together multiple perspectives in order to identify spatial, social and policy transformation with positive outcomes for peripheral communities. The research question concerns whether a holistic approach to spatial and enterprise planning can facilitate more sustainable growth; and whether a bottom-up participatory approach can inform more appropriate solutions to water challenges for female entrepreneurs. The conclusion presents the framework for further academic inquiry through a social innovation lens, with a view to greater transdisciplinarity between disciplines. This 'networked cooperation', is defined as a core aspect of social innovation in the contemporary body of knowledge, where multiple stakeholders work towards shared outcomes for social transformation, within a collaborative ecosystem is of relevance in our case (Horgan and Dimitrijević, 2018). Social innovation in the built environment occurs over phases - from network building, to framework formation leading to eventual solutions - be they architectural or otherwise (Horgan and Dimitrijević, 2021). Moulaert and MacCallum (2019:92) emphasise the diversity of relationships that provide the basis of a framework for action research on social innovation, and how "plurality in the understanding of the dimensions, practices and processes of social innovation should always be part of the process leading to a workable analytical framework". This is an important principle, given that "social innovation is highly contingent of its socio-political, spatial and temporal context", and that the "conditions for 
enabling transformative social innovation can be better understood in light of lessons from the past" (Moulaert and MacCallum, 2019:92). The particular context of peripheral urban settlements around Cairo - a number of them known as the 'Forgotten Villages of Greater Cairo' - necessitates a social innovation approach to sustainable development, particularly as such challenges are often present because of pressures exerted on already limited resources. These settlements are adversely affected by successive planning failures, laying bare the limits of established economic systems to support equitable communities, and anthropogenic climate change - as identified through the conducted research. Specifically, issues around the lack of adequate water infrastructure and its negative impact on marginalised communities including their opportunities for social mobility have significant overall impact. Although the research was conducted in 2018 and 2019, given how the more recent COVID-19 crisis has brought home the importance of clean water and sanitation services for vulnerable communities, this paper is timely in proposing a blueprint for a strategic roadmap to address 'wicked societal challenges'.

\section{Setting the scene: Urban Settlements in Greater Cairo and their planning challenges}

Egypt has a notable history of planning shortcomings and development failures since the middle of the twentieth century, many due to ill-considered strategies for new settlements outside the metropolitan conurbation. Many of the new cities built in the hinterland of the capital are not fit for purpose, catering from middle to high-income groups who are reluctant to relocate from Cairo's urban centres, despite of the earlier attempts (1970s-1980s) to develop a new master plan for the city, which would direct urban growth to towns towards the east as well as west parts of it (Khalifa, 2015). The 1970s 'New Towns' plan to relocate the residents from agricultural lands to the desert failed due to affordability, remoteness and lack of essential services, and in the 1980s the government shifted the perspective towards the development of 'New Towns' while providing housing environments that adopt 'site-and-services' and 'self-help' concepts, which were still unaffordable (Sutton \& Fahmi, 2001). In the 1990s, the government began to pay attention to security and social infrastructure, and the need for social resilience within communities. A national survey was conducted and revealed that there were 1221 informal areas, 1201 are upgradable and 20 are to be removed or replaced. The intervention program involved two stages:

(1) Informal Settlement Development - providing basic services and infrastructure

(2) Belting programme- limiting the growth of informal settlements.

Studies into these initiatives by Khalifa (2015) noted that the whole programme suffered from a lack of community participation, and engagement with key stakeholders. In the first decade of the $21^{\text {st }}$ century, pressure began to build on the government to respond to enduring spatial equalities and address imbalanced development strategy. In 2008 for example, the ISDF (Informal Settlements Development Fund) was established, adopting a strategy to differentiate between unsafeareas and unplanned areas; as unplanned areas were defined those that are not subject to detailed plans, land subdivision plans nor compliant with planning and building laws and regulations. Unsafe areas are viewed as posing risk to life, health and tenure or having poor housing or located in hazardous sites that pose risk to health. According to this classification, $60 \%$ of urban areas are unplanned while unsafe areas are between 1-5\% of the total urban areas. The general policy of ISDF advocates in situ upgrading, without relocation of people in order to preserve social networks and to maintain their source of income (Khalifa, 2011). 
Nuanced approaches to planning for informal settlements encourage making connections among previously siloed or separated functions of government and society. The underlying reasons that contribute to challenges are deeply related and cannot be viewed in isolation. Discussion on informal settlements in Egypt in the context of this study is centred on a) basic reasons, b) key characteristics, and c) aspects of interventions.

Informal settlements have emerged and developed into a phenomenon for various reasons that can be clustered under two wide categories:

(a) Population Growth: Growth from natural increase and high birth rates as well as a result of rural-urban migration (El-Batran \& Arandel, 1998) caused an increase of 30 percent in Cairo during the last century.

(b) Housing Policies (Khalifa, 2015):

Following earlier socialist policies and a prior wave of investment in the public housing sector, Sadat's 'Open-Door' economic policy in the early 1970s attracted private and foreign investments to the country which resulted in a general norm that rendered the state responsible for low-income housing, and the private sector responsible for supply for higher-income groups. This co-incided with the policy of New Towns to relocate residents from agricultural lands to desert areas and the provision of housing based on site-andservices.

The key characteristics of informal settlements in Egypt can be discussed in physical and socioeconomic terms. In terms of the former, informal settlements are of incremental nature with construction and urban elements being determined via existing street patterns, buildings, topography and natural and man-made features, but lacking key facilities, amenities, services and infrastructure (Arandel \& El-Batran, 1997). Informality, on the other hand can be dually defined: informal areas that grew on public land-predominantly desert, and informal areas that grew on private land- predominantly agricultural land (Khalil, 2010) - although Egyptian law does not make a differentiation, seeing both as unplanned areas (a recent UN Habitat study aims to clarify each other's characteristies). The informal settlements on agricultural land are located on the urban periphery and are of a generally better quality, while the ones on desert lands can range from low- quality one storey residential buildings to better quality 6-8 story buildings; also, there is a large stock of vacant buildings, although the density of informal settlements is double the density of Cairo as a whole, with older informal areas being more densely populated Denis \& Sejourne (2002), and more highly so, within the informalities of Greater Cairo Region (Khalil \& Gammaz, 2019). Physically, the structure of the settlements shapes according to the type and strength of social relations between various groups and families. Members of the community cooperate to provide public services such as waste collection, street lighting, street cleaning, and public landscaping (Eldefrawi, 2013). Social norms, including the need for privacy, isolation or integration, contribute to the shaping of the urban fabric. The residential streets are narrow so as to restrict strangers and control pedestrian traffic but allow to for multiple activities like: extended home activities, extended work space to the street, extended cafés to sidewalk or pedestrian pathways, extended ceremony hall and extended playground. Also, the plot and building pattern in the settlements are created with a compact pattern and an order that is respecting the proximity of services, work and home, with the distances between them are 
walkable (Eldefrawi, 2013). It is worth noting that informal areas are developed without the intervention of technical planning expertise, hence they manifest spatially the actual needs of grass root development in contrast to formal theory- based planning advocated by the planning profession in other parts of the city (Khalil \& Gammaz, 2019).

Development strategies that take a bottom-up approach inherently necessitate the bringing together of a diverse set of disciplines and knowledge - to inform a holistic evidence base working towards shared outcomes for communities in a given location. In general, this can be considered as part of a social innovation methodology, informed by place-making principles, where the tacit knowledge of communities, and their inherent resources, are considered important assets with which to shape development proposals (Horgan, 2020). Promoting knowledge exchange - and iterative collaboration - between disciplines requires the translation of data and concepts, on issues such as informality, usage and behavioural patterns and other dynamics that can provide a fuller understanding of the root causes of spatial inequalities. Interdisciplinary research of this type - uncommon in architectural research, and peripheral in the study of business and entrepreneurship - requires a composite framework, informed by innovative uses of methodology.

\section{Perspectives from the participating disciplines: a composite framework}

One of the bigger challenges in terms of interdisciplinary research is defining the space of inquiry between macro disciplines ('radical interdisciplinarity' according to Winskel, 2018); related challenges can include '.... meeting of physical science's positivist laws and determinisms and social science's interpretivist hermeneutics...problem definition; data, evidence and proof; research methods; unit and scale of analysis; the role of non-academic stakeholders and funding and reward structures' ( $p$ 78). In creating a framework for our research, we aimed to go beyond the challenge of 'subordination-service exchange.....when social science plays a subservient or 'gap-filling' role' (Winskel, p.79). Whilst the debate about the efficiency and effectiveness of interdisciplinary approach in identifying and addressing complex challenges is an on-going one, an interest is increasingly expressed in terms of 'transdisciplinarity' as an approach, which aims to integrate from the conception phase of the inquiry, non-academic stakeholders, via 'knowledge production and exchange' (Salama, 2011, 2019; Winskel, 2018). For the purposes of the project on which the present paper is based, we followed a transdisciplinary approach, blending perspectives from urban planning with focus on water challenges, social innovation, architecture and womenled entrepreneurship.

Entrepreneurship for this particular project takes into consideration ways in which members of the community proactively engage themselves in coming up with enterprising solutions which not only aim to resolve the immediate issues that they are facing, but also to generate wealth for them, as wellas for the community in general. This is a particular form of social entrepreneurship which has its roots in community-based understanding of common assets and in ways in which their well-being can influence the well-being of communities too (Cohen and Munoz 2016). Water is, in that sense, a community asset and ways in which its condition and provision is influencing the community dynamics (production/food/sanitation) plays an important role in how its interrelated challenges are perceived and possibly addressed. In addition to that, there are ways in which entrepreneurship is developed despite the water-based challenges faced by such 
communities. Access to safe water is of utmost importance to the quality of life of women and children, and this challenge is exacerbated in the urban settings where most of the poor reside (Anderson et al, 2016). Women, in particular, could utilize the time devoted to water sanitation and wastewater management in other productive activities; in this context, the quality of water could be impeding the general quality of life and the quality and outcome of women's business and entrepreneurial activities. Additionally, we also scoped ways in which entrepreneurial practices in other sectors (non-water related), inspire and affect these communities- and in particular, the women entrepreneurs in them, whilst also supporting the expansion of a mindset which is focused on addressing a social challenge as an entrepreneurial opportunity.

The second perspective forming the inter-disciplinary framework comes from Apchitecture and Urban Planning and is focusing on the assessment and re-conceptualization of space as context. Lefebvre's $(1968 ; 1974)$ work, in particular, which is increasingly informing both)

Entrepreneurship as well as Architecture because of the importance it places on society and the urban space, allows for the creation of novel inter- disciplinary and multi-layered approaches to the study of the identified challenges in a context such as the one that the project focused on. Lefebvre's $(1968 ; 1974)$ key tenets - to guarantee citizens' rights to access dignified housing and employment - are echoed in the United Nations Sustainable Development Goals, in particular SDG 11- a commitment to make cities and human settlements inclusive, safe, resilient and sustainable (United Nations SDGs). For instance, Lefebvre's $(1968 ; 1974)$ tri-partite framework facilitates analysis of the imagined/conceived in studying stakeholders' settlement-relevant interventions, the measured / perceived in terms of economic and entrepreneurial practice, and the experienced / lived in terms of the socio-spatial context (Salama et al., 2016). Within this particular framework, it would be interesting to observe ways in which the space of solutions is created and policy /practice is developed. As a methodological implication, the community approach and methods of participation in scoping gain significance, as policy interventions can be framed via partial viewpoints of perception, and can be divided via the agenda of different stakeholders. This embedded approach helps researchers to understand the social dynamics at play in urban settlements and to effectively align agendas around mutually desired outcomes.

According to Lefebvre (1991)"the spatial practice of a society is revealed through the deciphering of space. [...] The specific spatial competence and performance of every society member can only be evaluated empirically. [...] spatial practice consists in a projection onto a (spatial) field of all aspects, elements and moments of social practice. [...] Like all social practice, spatial practice is lived directly before it is conceptualized; but the speculative primacy of the conceived over the lived causes practice to disappear along with life, and so does very little justice to the 'unconscious' level of lived experience per se (Lefebvre 1991, p.38, p.8 \& p.34)".

\section{FIGURE 1 HERE}

Thus, spatial practice and social practice inevitably impact one another. In other words, these practices operate within a particular political process and, in turn, as part of a planning culture. Therefore, understanding the relationships between both spatial and the social practices becomes essential in order to learn more on the production of urban spaces in the different contexts, such as the ones referred to in this paper. This is particularly important, as according to Kevin Lynch (1981), 'sense is the degree to which the settlement can be clearly perceived and mentally 
differentiated and structured in time and space by its residents and the degree to which that mental structure connects with their value and concepts - the match between environment, our sensory and mental capabilities, and our cultural constructs (Lynch, p.118)'.

A multitude of diverse attributes is required for effective urban performance at various scales, ranging from the immediate context of both planned and unplanned developments. Following Lefebvre's postulation, these qualities can be framed under a cycle of three main symbiotic pillars: the imagined, the measured, and the experienced, which contribute to the development of insights that elucidate various parameters for describing and exploring urban performance in unplanned developments. These three pillars stem from Lefebvrian arguments and Lefebvre's theory on the production of space, which postulates a triadic relationship of three different but related types of spaces: the conceived (imagined), the perceived (measured) and the lived (experienced). The current body of knowledge on Lefebvre's work suggests that the 'conceived space' is abstract and tactical and where authority functions, the 'perceived space' is a pragmatic, physical space encompassing flows of investment, workforce, and information- and that this where the conceived and lived spaces are construed. In a recent contribution and following their earlier work, Salama and Grierson (2019) suggest that the 'lived space' is the most subjective space, involving the actual experience of individuals that is performed in the 'perceived space' and as a result of the 'conceived space'.

In order to work towards shared goals for boosting urban sustainability that addresses prevailing inequalities, social innovation in the built environment is required. Increasingly, this depends on the developing holistic policy that can facilitate a roadmap that relies on agile development methodologies which encourage deep community engagement. Examples of this approach from other parts of the world include the work of Aravena and Mehrotra on ephemeral urbanism where solutions are tested and prototyped in-situ with communities (as found in Dimitrijević, 2019).

\section{Water in urban settlements: governance and challenges}

Egypt faces a predicament of pollution of water resources by industrial wastewater, agricultural drainage water as well as municipal wastewater - all presenting threats to the health of its citizens especially in the informal areas. Water management falls under the responsibility of quite a few Egyptian Ministries; the most important ones are the Ministry of Water Resources and Irrigation (with 9 distinct units), the Ministry of Agriculture and Land Reclamation, and the Ministry of Housing, Utilities \& Urban Development. Further ministries are involved with a role in water policy formulation as well as secondary water management operations are the Ministry of Health and Population, the Ministry of State for Environmental Affairs, and the Ministry of Local Development. Related challenges require the mobilization and management of all resources in an integrated manner (Abdel Meguid, 2017); this is particularly the case as the amount of accessible water resources is fixed, while water demands are growing as the population continues to grow. Effective waste management is a challenge in Egypt due to the high population growth rate and the swift urbanization. The implementation of an effective management system in the area of the study, is hindered by lack of credible information, financial resources and its complexity (Burntley, 2007). Water quality problems in Egypt vary according to the location and depend on factors such as water uses, population densities, consumptions per household, sanitation systems, industrial discharges, and agricultural runoff. Discharge of untreated wastewater (both industrial and 
domestic) affects the quality of water. In addition, previous studies have shown the effect of deteriorated old water infrastructure on the quality of potable water on the household level within informal areas in Greater Cairo Region (Attia \& Khalil, 2015)

\section{Women entrepreneurs in informal settlements and links to water as part of the context and entrepreneurial opportunity}

Understanding informal settlements as an entrepreneurial context has its own challenges, as their conditions are significantly different from more commonly acceptable ecosystems of entrepreneurship, where institutional norms, systems and actors allow for entrepreneurial activities to be developed based on the discovery or creation of an opportunity (Audretsch and Belitski, 2017).

From GEM data (Allen et al., 2007) it is suggested that female entrepreneurial activity is considerably greater in low- and middle-income economies in comparison to how much of it has been documented till now; according to Nasrullah and Dickson (2009) this calls for an investigation of specific national and cultural influences which might be influencing ways in which entrepreneurship is enacted and developed.

Context, as a subfield of study within the discipline of entrepreneurship has been given extensive reviews in relevant literature- and it is a well-established concept in the study of architecture and urban settlements. Context can be defined as "circumstances, conditions, situations, or environments that are external to the respective phenomenon and enable or constrain it" (Welter, 2011, p. 167). Context can be encompassing of culture, individual ethnicity, social, economic, and political aspects involved in entrepreneuriál activities (Mitchell et al., 2002a), that produce both attitude as well as entrepreneurial behaviour differences (Shane 1994).

Research has indicated that individuals, can be imprinted through a variety of sources, such as through economic conditions, institutional conditions, family members, or other individuals (Mathias et al, 2015). Exploring how the imprinting process influences marginalized women entrepreneurs in such deprived areas is vital to understanding their selection of current and potential future opportunities. Since the government is not equipped to solve all of the country's problems, entrepreneurial agents would be looking towards the development of relevant forms of social entrepreneurship, which can address economic growth, as well as the responses to social needs and social exclusion (as indicated by Nicolopoulou, et al, 2014).

Recently, Egyptian youth have established, and are leading, several social enterprises with a yet untapped potential to contribute to Egypt's development (Abdou et al., 2010) Several such social enterprises work mainly with women in rural areas and distressed communities with the aim of empowering them. Also, NGOs with a social enterprise element are focusing on empowerment instead of providing financial aid- for example programmes in Upper and rural Egypt are training women in embroidery and other handicrafts. Usually, the women work either at their homes or in training centres and receive payment per item produced, thus, over time, women involved in these initiatives are motivated to set up their own businesses, although their effectiveness in terms of the impact on women's income, empowerment and capacity building are always the topic of further investigation (Guerin and Marius-Gnanou, 2005). Economic growth and job creation are at 
the top of Egypt's current economic agenda, with unemployment remains a problem predominantly for women who are marginalised in economic activities; data from CAPMAS (2019) shows unemployment rates among women to be more than double that of men. Although in 2012, 3.6 million Egyptians were reported to be entrepreneurially active (Hattab, GEM Egypt 2012 Report, 2013), reports show that Egypt is still facing ongoing challenges when it comes to the rate of female entrepreneurs in the country. Women face serious challenges in terms of participation in economic life in Egypt in general. According to Krafft and Assaad (2014), 75 percent of young women are not in the labour force, and, although Micro and Small Enterprises (MSEs), constitute 98.5 percent of the private sector, female-owned MSEs represent, only 10-15\% of registered private firms (IFC, 2005). In rural areas, farming and cultivation is a major source of employment for females (CAPMAS 2008).

El Mahdi (2006) reports that female owned enterprises in the country account for a larger percentage of enterprises in rural communities than in urban areas, where women face additional severe problems than in other regions, most prominently, lack of profitability, due to limited access to markets, which forces them to conduct their businesses inconfined rural areas (IFC 2005). Egyptian women, mainly living in the lower socio-economic groups, are the main breadwinners for their households, if illiterate, divorced or widowed, are in need to generate a second income to assist with the everyday ongoing expenditures, although according to The UNDP Egypt Human Development Report (2005) they operate entrepreneurially in conditions of informality. Existing power structures in Egypt hinder women's work and empowerment in the marginalized areas, due to the above-mentioned challenges. Drawing the bigger picture with regards to these challenges, it is relatively easy to understand how such contexts equally present challenges in terms of the infrastructure and access to resources.

Filtered or purified water is a dream for the women in the Greater Cairo unplanned areas, especially with the increase in water issues regarding contamination and pollution. Households that obtained water filters have a long process of instalment repaying, although they are already in need of an upgrade to a 7-stage filter instead of a 3-stage one, currently in place, although there are serious challenges in obtaining those.

The role of the men is also important in relation to how the structure of work is conceived for women entrepreneurs in such contexts- with co-location of the entrepreneurial activity within a household as the preferred option. Ventures that focus on the production of food suffer from lack of hygienic conditions in terms of water access and use, as well as from potential clients' complaints. Such potential risks tend to ruin the possibilities to develop entrepreneurial activities, whilst the overarching expectation is for the government to step in and resolve infrastructural and access issues,

\section{Methodology: depth, participation and engagement in word and images}

The research process followed was participatory and ethnographic, and it involved, apart from 12 site interviews, engagement via a visuals-based exhibition focusing on materials from the studied community, during an outreach and engagement event in one of the academic institutions involved in the project. 
The ethnographic approach allowed the researcher to obtain an insider view and understand the social experiences of the participants by exploring them in-depth and to collect rich detailed information (Bryman 2008). A purposive sampling method was used to select women to participate in the study. Purposive sampling allowed the researchers the freedom to choose the respondents (Saunders et al., 2009:237). One of the researchers had former knowledge about women who are affected by water issues over and above about the pool of respondents. Moreover, she had conducted parallel studies in a similar context which allowed her to meet a substantial number of female entrepreneurs embedded in unplanned areas in Egypt.

The engagement event focused on global outreach and projects with impact; the method used for the engagement with the visual materials was based on principles of rapid brainstorming. Rapid responses were sought from participants on the basis of two core topics: 'what innovation/social innovation solutions could be applied in order to tackle depicted challenges' and 'what are the entrepreneurial responses that could develop in order to tackle the depicted challenges. Answers were collated in flipcharts and were further elaborated on, in conversation, in order to generate potential future strategies in related communities. The typology developed and presented at the end of the paper merits further examination in future research as to the suitability of such solutions.

In terms of the first stage of the project, identification of stakeholders took place as well as the mapping of their key problems and opportunities, including the definition of the key water management issues in the areas of interest to the different stakeholders involved. A typology of the water management issues in comparison to the area classification was subsequently outlined (Table 1) as a preliminarily output of the project activities. According to Dana and Dana (2005), an inquiry based on inductive qualitative methodologies is a prevailing paradigm in sociological and anthropological research; such inquiry would be based upon thick descriptions of agents and their interactions with context (Geertz,1973). This approach would respond to challenges identified by Gaddefors and Anderson (2017), who argue that the current methodological individualism of the prevailing paradigms, does not leave explanatory room for the role of social context; Patton (1982; p.10) argues that "The methodological mandate to be contextually sensitive, inductive, and naturalistic means that researchers must get close to the phenomenon under study. The institutional researcher who uses qualitative methods attempts to understand the setting under study through direct personal contact... through physical proximity for a period of time and through the development of closeness."

Based on the pre- adopted pro-community approach in water resource management and the participation of one of the most vulnerable segments of the community-i.e. women- stakeholder discussions were held, which can have the potential to ensure fuller participation of local people in development issues and impactful changes in marginalised communities, at a later stage.

IMAGE 1 HERE

IMAGE 2 HERE

IMAGE 3 HERE 


\section{Visual Ethnography}

The project engaged with a particular branch of ethnography- visual ethnography (Lenette and Boady, 2013), which was done on the basis of collection of several photographs of the surroundings. Ethnography and visual methods produce richer and more contextualized data. Pink (2012: 6) highlights that visual methods are a 'field for interdisciplinary scholarship' which expands and enhances 'the production of knowledge and ways of knowing' (Pink, 2006: 53). Lenette \& Boddy (2013) assert that such methods allow nuanced discoveries of complex themes, permitting better forms of data to emerge. The strength of images is their richness in context and the amount of specific information they can transfer (Flick, 2007). In conducting a visual ethnography, we were able unlock and 'to understand specific themes within participants' (Lenette and Boady, 2013; p 72), everyday realities as well as gender and water issues. It also allowed us to understand the hidden layers in this marginalised context, following Steyaert (2004, p.10) who outlines that '...the everyday is the scene where social change and individual creativity take place as a slow result of constant activity. Innovation is not the Great Renewal but the daily effort of thousands of small steps which -after all- make a difference'. These 'small steps' mentioned by Steyaert (2004) were recorded through the visuals which later helped in creating a rich narrative of the entrepreneurial endeavours pursued in these communities.

\section{Analytical method}

We gathered the photos into different themes and counted how many themes appeared across all of the collected photos (Thomas, 2009). Thematic analysis was used to analyse the findings. This included classifying the various themes that developed from the various data collected (Bryman 2008, Harding, 2013). Thematic analysis is "a method of identifying, analysing and reporting patterns within the data" (Braun \& Clarke, 2006, p. 77). It was also utilised to analyse the qualitative data gathered during the site interviews.

The process of analysis (Figure 2) started with reading and familiarizing with our data and taking initial notes. We went through a thorough overview of all the data we collected before we start analysing to get a general understanding of what is going on (Creswell 2003). The next step was narrowing the data to units of meaning through coding each of the themes (Bryman 2008). Coding reduced the data into workable chunks. Afterwards, we identified patterns among the codes, and came up with the themes. Later we made sure that our identified themes are accurate representations of the different collected data and we named our themes (Figures 3 and 4). Lastly, we wrote our data analysis.

\section{Outcomes from the experts' stakeholder engagement workshop}

As outlined above, an expert workshop, took place during an engagement university-focused event related to impactful global projects, where we had the opportunity to engage with an academic community specialised in social innovation-driven, technological, governance and management solutions; the interactions, which, as described above, took place via the method of 'rapid brainstorming' with a focus on innovation and entrepreneurship, highlighted the following potential interventions:

\section{Entrepreneurship- driven solutions:}

- Capacity building in terms of specific trades or schemes 
- Water couriers ('just drink'): small fee to transport water /distribute to communities (business opportunity)

- Water point committees and the development of partnerships with established institutional stakeholders like NGOs, Banks and others

- Introduce digital (e-payments) to boost savings and safeguard funds/sales

- Product differentiation (clean/bottled water- different colour per village) to prove purity

- Community groups to share water saving ideas and good practice

- Explore the set-up of water user associations

- Set up self-help child care to facilitate the process of enterprising in water for women

- Raise awareness about global dimensions of the problem and highlight set of barriers in the context

\section{Innovation- driven solutions:}

- Permaculture

- Water tanks for intermittent supply (between communities)-sharing knowledge with best cases from Africa

- Rainwater harvesting systems in homes

- Help develop smartphone apps to connect and share; reporting via GPS

- Implement simple testing kits to identify problems

- Use textile/knitting skills to create water filters

- Create a thread impregnated with water purifiers

- Implement behavioural change by a campaign to make water collection management a male activity

- Communication and network development to share local learning Matching such solutions to the requirements of the specific community studied, or to comparable communities was only done at conceptual level, as we did not seek to affirm with participants their suitability and implementation potential, however this matching merits further empirical investigation and can be the basis of a future project as well.

\section{Social innovation as a critical component of a strategy to create a roadmap for future proofing development in informal settlements- insights from a 'lived', 'perceived' and 'conceived' perspective}

Lefebvre's (1968;1974) tri-partite framework facilitates analysis of the imagined/conceived in studying the role of stakeholders in settlement interventions, the measured / perceived in terms of economic and entrepreneurial practice, and the experienced / lived in terms of the socio-spatial context. Moreover, as Rose (1993) argues, being defined as a woman might entail feeling confined and constrained by space, the gendered practices and power structures of everyday life constrain women's space and thus produce and reproduce space that is gendered (Rose, 1993).

Within this particular framework, a space of solutions is created and policy /practice is developed. Via our socially embedded research methods, our discussion should be able to inform policy interventions without the risk of sharp divisions defined by the agendas of different stakeholders. 
At high-level, social innovation responds to an unmet social need - which necessitates the coming together of multiple actors in concert to propose and test solutions (Moulaert and MacCallum, 2019; Mulgan, 2019). In the design of urban settlements, interdisciplinary - and transdisciplinary collaboration is promoted in the UN New Urban Agenda, and echoed at the ground level in the smart city strategies of metropolitan conurbations around the world. Horgan and Dimitrijević $(2018 ; 2019)$ have found that social innovation in the built environment occurs through non-lineal phases, in which stakeholders form networks that develop collective strategies for transformation in the built environment. Resultant solutions can be manifest as physical infrastructure, technology or smart services and in inventive policy architecture. Many governments see the concept of the smart city - where technology plays a leading role in the delivery of social innovation as a route to addressing spatial inequalities, while upgrading social infrastructure for modern times (Horgan and Dimitrijević, 2019). However, genuine, holistic social innovation that tackles the root causes of spatial inequality is dependent on robust governance, ownership and participation among stakeholders (Horgan and Dimitrijević, 2019). Social (and digital) infrastructure or solutions can be proposed through a dialogue with stakeholders, once problems have been diagnosed in a holistic 'design process', emphasising participation and openness (Mulgan, 2019). Such an ecosystem, where community and academic actors sit at the table alongside commercial and local government interests represents a quadruple helix, and is widely considered as a more future-proofed approach to sustainability. In the context of Egypt, social innovation offers pathways for local communities to devise tailor-made responsive solutions that make best use of their exiting resource and capacities. Access to water remains a persistent challenge in informal settlements in Egypt, having a disproportionally negative impact on particular groups such as women from low-income backgrounds.

Most forms of settlements are faced with Water challenges; in the particular areas of unplanned urban settlements in Greater Cairo, these challenges have to do with stagnant waters from nearby informal production units, as well as the lack of proper infrastructure which pollutes water on the way to households. The water challenges in these areas are defined as 'negative sanitation systems' which means 'directly discharging highly polluted sewage into water irrigation water streams, canals and drains or on-site facilities such as cesspools and trenches' (Azeem, 2014, p. 9). We have observed small-scale household-based solutions being developed in order to address the challenges- small-scale ingenuity-driven ones, such as adding cotton under the water taps in order to filter the water. Indeed, as one of the stakeholders interviewed told us, 'there is a level of ingenuity in Egyptians, there is always a drive to recycle or to upcycle-nothing gets wasted here'.

Nonetheless, there seems to be a concurrent disconnect between the capacity to develop innovation/innovative solutions and the capacity to effectively deploy them in settlements, at the community level, outside of each household; yet, as one of the interviewees confirmed, there is a very good chance that once a solution is adopted and promoted by a key leadership figure, this solution can be taken much further in terms of adoption by the community. There is an element of 'emulation of leadership', which together with a sense of 'belonging' could help facilitate the adoption of innovative solutions and possibly become a step towards an effective scale up to the community level. This can be viewed as social innovation through a process of place-making (Horgan, 2020), and could include engaging potential partners that can bring solutions to commercial fruition. In Egypt, there is a large cohort of business and enterprises already working 
on social innovative solutions for specific at-risk groups, and their role could be important in developing related interventions.

From a normative, gender- informed perspective, Ibrahim Huber (2018) notes that the spaces of males versus females in terms of water management in settlements are quite different, in that the management aspect of both the water as well as the land is typically a male domain, whilst the quality of water, particularly pertaining to caring for health of the family, together with the management of solid waste is predominantly considered a female responsibility. This element of ownership of the solutions to water is pervasive in terms of envisaged participatory approaches to the management of water and its solutions. Azeem (2014) for example, differentiates between approaches to resolving water challenges, which are seen as purely technical (eg:centralization in one facility of wastewater for treatment) versus socio-technical, which allows users to also participate in its management and ownership, thus de-centralising towards the people involved. This reflects definitions of social innovation such as that of the Center for Social Innovation at Stanford University which defines social innovation as 'the process of developing and deploying effective solutions to challenging and often systemic social and environmental issues in support of social progress', or that of Westley (2008, p.1), who claims that "social innovation is an initiative, product or process or program that profoundly changes the basic routines, resource and authority flows or beliefs of any social system. Successful social innovations have durability and broad impact. While social innovation has recognizable stages and phases, achieving durability and scale is a dynamic process that requires both emergence of opportunity and deliberate agency, and a connection between the two. The capacity of any society to create a steady flow of social innovations, particularly those which re-engage vulnerable populations, is an important contributor to the overall social and ecological resilience".

Within the framework mentioned above, it would be really challenging for one technological or managerial adjustment, particularly if driven from a centralized perspective, to create systemic, scalable change. The challenges would rather be addressed from within an 'innovation ecosystem' of water in and around the settlement communities- and, in this particular case, highlighting the role of women in it. The response requires a holistic approach to developing solutions that allows for the participation of multiple disciplines and viewpoints. Our insights from architecture highlight that there is also a growing understanding of the need to allow new narratives around development to come to the fore.

In the process of conducting our ethnographic research, we observed that the residents of the deprived area studied, were eager to participate in any form of collaboration, regardless at an individual or a collective level, which corresponds to Ayob et al.'s (2016) framework on social innovation pathways. The participants disclosed that a positive societal impact and improving the quality of life for their whole community is what they were looking for. Moreover, one interviewee stressed that women entrepreneurs and SME owners are in dire need of professional training in order to be able to address managerial and finance -focused issues. Bearing on the fact that several enterprises are not operating within a legalized framework however, in effect impedes the entrepreneurs from accessing the expertise they need.

For that reason, a general mind-set issue around legality and legitimacy should be tackled if innovative solutions driven from within the community are to be fully adopted and scaled up. That 
mind-set shift also bears on the available funding and the perceived notion of governmental topdown support. The other disconnect in a socially-targeted innovation ecosystem is the lack of a culture of innovation- the drive to experiment, and to do things differently, subsequently moving from a prototype to scale; in other words, systematizing and legitimizing the ingenuity and experimentation with 'rough solutions' which might be taking place at the level of the household, by moving it into the community. Finally, 'unlocking' women from their more traditional roles in the cycle of water issues, and facilitating them to have a say in management aspects of related water-focused processes could be one of the ways forward. In developing an appropriate framework, the assembled knowledge areas must collaborate on the study of environmental and contextual factors to support the understanding of the role of regional and local government in producing spatial inequalities. Aspects of government, ownership, participation and technology use should be considered alongside the cultural context, too.

\section{Elements of a blueprint for a strategic roadmap based on social innovation}

Identified challenges may be addressed with some interim solutions, which could form a central spine of a strategic roadmap in order to forge ways forward:

- Developing and fostering a culture of innovation in the local écosystems through community programmes with local outreach points, via a dialogue process with stakeholders and also women inhabitants of the settlements was an important insight from our study

- Scaling out successful prototypes which have been implemented successfully by organisations such as that of BLACD, Egypt could be helpful (the organization has been effectively implementing a sustainable development - focused model for clean water and sanitary latrines for more than 6,000 people in 12 villages and is scaling out further). An additional step in this direction would be to support the creation of self-governed learning networks/hubs operating with a focus to exchange knowledge and expertise on the basis of best practice and growth

- Further investigation and learning would have to be afforded in order to understand ways in which water-focused innovation (in terms of technical or socio-technical systems) is developed in Egypt or it is adapted from international models. On the basis of better understanding the nuances of the innovation/technology transfer process, entrepreneurial incentives could be created in order to support production or adaptation with a scope to further scale out, via the creation of specifically designed programmes to that end.

- The creation of 'Living labs' and similar participatory platforms for social innovation in designated areas could also be developed; these could comprise a mixture of digital and physical spaces and platforms, combined into a rich and robust ecosystem for multistakeholder collaboration.

In order to sketch ways forward with the application of such a roadmap, we have compiled a composite typology which identifies the different types of unplanned urban areas co-related to the different water challenges they are faced with. 


\section{TABLE 1 HERE}

This typology can be more widely applicable to a number of unplanned areas, such as:

- Imbaba which is located west of the Nile and northwest of and near Gezira Island and downtown Cairo. A research by the Higher Institute of Social Services (HISS, 1989) in Imbaba, an informal zone located on agricultural land, extends on 3000 Feddan approximately, with a population that must have exceeded one million, and with abundant service activities and workshops. Historically, Imbaba was considered to be a formally planned area with bulky amounts of homogenous public housing from the 1960's surrounded by agricultural privately owned land. After the independence in 1952 mass housing for low-income workers added entire district-scale estates to the city, such as in Imbaba.

- The 1992 earthquake in Egypt was a major cause of migration and mobility within the Greater Cairo Region. The earthquake was $5.8 \mathrm{R}$ strong and its center was approximately 35 kilometres south of the center of the Greater Cairo Region. Masaken El-Zelzal (literally means earthquake) is located on Mokattam Hill. People were relocated to governmentprovided low-cost housing there after the 1992 earthquake. Most of the people there had previously lived in other poor areas of Cairo, including informal settlements. The area is remote and poorly networked with the rest of Cairo, with very basic infrastructure for sewage, water and electricity.

- Al-Darb al-Ahmar, which is considered a historicalarea in Cairo, signifies the traditional urban fabric of medieval Islamic Cairo, yet the area is characterised by a condensed population and lack of social services (Aslan, 2006). Al Darb al-Ahmar households are among the poorest in Egypt, as people have to survive on less than the equivalent of one dollar per day.

- The City of the Dead aka Cairo Necropolis is vast Islamic-era cemeteries on the edges of old historic Cairo. It extends to the north and to the south of the Cairo Citadel, covering an area roughly 4 miles long. Its inhabitants' mainly illegally occupy the tombs or carry out a task concerning the funerals as being gravediggers; others find occasional jobs out of the place in small shops. Cairo's 'Cities of the Dead' have entered the Third World settlement literature as a unique kind of squatter settlement.

Finally, concrete interventions and support could take place in terms of women entrepreneurs in order to support their dual mission of contributing to economic growth, whilst adding value towards social and community outcomes. These could include:

- Implementation of mentoring systems since researchers have highlighted the significance of imprinting to individuals and potential entrepreneurs through early mentoring (Azoulay et al, 2011).

- Women's active participation in water and sanitation projects can be indispensable in any water related project because of their key roles in the maintenance of water, sanitation and hygiene at their own, domestic level.

- Establishing cluster communities in underprivileged locations offering opportunities for female entrepreneurs to benefit from shared facilities and experience (according to insights acquired from comparable cases presented at ENID annual conference, 2019). 
- Understanding and strengthening of the presence of women entrepreneurs in the different marginalized regions across Egypt; this could entail in-depth field work and tailored programs in accordance.

- Incorporating gender considerations into new projects by aid agencies, NGOs or government- an essential component to reinforce gender-mainstreaming initiatives.

We are proposing a combination of the elements derived from the typology, blending insights from all participating disciplines through the select theoretical framework (table 2). Our proposition is open to further academic and practice-based discussion and investigation.

\section{TABLE 2 HERE}

\section{Concluding reflections and way forward}

Social innovation can promote agile processes to prototyping new public services, involving multiple sectors as well as stakeholders through open ecosystems. For urban settlements undergoing rapid expansion, social innovation can help both communities and governments to build resilience in the face of resource gaps - often making use of advancements in technology and improvements from other disciplines to support social transformation - the process itself becoming a catalyst for building community capacities from the bottom-up (Horgan and Dimitrijević, 2019). For the unplanned urban areas around Greater Cairo, input from different knowledge areas can offer valuable contributions- for example, in terms of our project and the study that we report on in this paper, the contributing areas included architecture and urban planning, as well as women-led entrepreneurship targeting economic growth, social and community impacts. As the world becomes increasingly urban, the drain on collective assets produces a need for a holistic evidence base to inform new models for urban governanceparticipation from the grass-roots can allow community ownership over development strategies. This could be key to providing for sustainable communities and managing inclusive and equitable growth in rapidly growing settlements.

The framework we are proposing in the present article, acknowledges these dynamics and seeks to learn from other cases and disciplines, building, thus, the potential in terms of scaling up and scaling out of solutions which might be identified or developed in the context. Subsequent research could look at barriers to place-based social innovation from a number of perspectives, mindful that these may be overcome through creative collaboration and cross-sectoral partnership. Collaborative co-design and social innovation methodologies can be further used to support the development of a roadmap, pathways and development process in which low-tech, smart or high-tech solutions could, in the future, be tested with the participation of partners for both behavioural changes, as well as service innovation. Models of transdisciplinarity popular in the practice of social innovation can promote insights collected through ethnographic modes of enquiry, design thinking and user-centred design. Such methodologies take into consideration the inherently iterative nature of social transformation that requires the continuous measurement of social impact to inform development strategies (Mulgan, 2019).

Similarly, the interdisciplinary framework proposed in this paper is informed by expertise from the field of social innovation as it pertains to the built environment, from the perspective of the 
creation of equitable cities for the future, taking into consideration all those elements which will be rendering the city resilient and sustainable in the holistic sense, in the years to come. While many settlements have had a marginalized or unrecognized status for many years, nuanced planning approaches in the Global South are bringing formal recognition to these areas. New research is required to both bring a new understanding of urban dynamics and interconnection, as well as to analyse, propose and measure the social impact of urban transformation. This should include the examination of community-based models which allow vulnerable or marginal groups to participate more fully in the and design and eventual delivery of policy and planning solutions that are contextual and responsive. When viewed as a networked approach to developing ) solutions to urban challenges, social innovation as a framework can provide a positive influence towards attaining the above.

Based on our experience in developing the present paper, specific methodological activities to be further explored may include the mapping of stakeholders and potential partners, ethnographic studies that inform the diagnosis of root causes and associated analysis, and invited participation of absent groups into a quadruple-helix collaborative holistic ecosystem. Hopefully these can provide pathways to creating further solutions in related areas in the future.

\section{References}

Abdel Azeem, S.M., Burham, N., Borik, M.G. and El Shahat, M.F. (2014).Trihalomethanes formation in water treatment plants and distribution lines: a monitoring and modelling scheme. Toxicological \& Environmental Chemistry, 96(1), pp.12-26

Abdel Meguid, M. (2017). Key features of the Egypt's water and agricultural resources. In: Negm, A.M. (Ed.), Conventional Water Resources and Agriculture in Egypt. Springer Berlin Heidelberg, Berlin, Heidelberg, pp. 1-61

Abdel Meguid, A. M. (2017). Ecosystem and Biodiversity in the Nile Basin Case Study:Lake Nasser" in Negm A1 M1 (Ed), The Nile River (pp. 305:353). Switzerland: Springer

Abdou E., Nelson, J., Greenwald, D., and Fahmy, A. (2010). Social Entrepreneurship in the Middle East: Toward Sustainable Development for the Next Generation. Washington, DC: Silatech, Dubai School of Government and Brookings Institution. Retrieved from http://www.shababinclusion.org/content/document/detail/1576/

Anderson, AR., Wallace, C., Townsend, L. (2016). Great expectations or small country living? Enabling small rural creative businesses with ICT. Sociologia Ruralis 56(3): 450-468

Angelidou, M., Psaltoglou, A. Komninos, N., Kakderi, C., Tsarchopoulos, P. \& Panori, A. (2017). Enhancing sustainable urban development through smart city applications. Journal of Science and Technology Policy Management, (9)2, pp.144-169 Retrieved from https://doi.org/10.1108/JSTPM-05- 2017-0016

Arandel, C.. \& El-Batran, M. (1997). The Informal Housing Development Process in Egypt, DPU Working Paper No.82, University College, London

Attia, S. and Khalil, H. (2015). Urban Metabolism and Quality of Life in Informal Areas, in M. Schrenk, V. V. Popovich, P. Zeile, P. Elisei, C. Beyer, eds., Proceedings REAL CORP 2015: Plan Together - Right Now - Overall, 5-7 May, Ghent, Belgium, pp. 661-674.Retrieved from http://www.corp.at/archive/CORP2015 19.pdf

Audretsch, D. B. and Belitski, M. (2017) Entrepreneurial ecosystems in cities: establishing the framework conditions. Journal of Technology Transfer, 42 (5). pp. 10301051. 
Azeem, M. (2014). Kom El Daaa Village Sewerage project assessment report. ENID. Retrieved from https://elnidaa.org/app/uploads/2019/07/CS11_kom_eldabaa.pdf

Ayob, N., Teasdale, S., \& Fagan, K. (2016). “How Social Innovation 'Came to Be': Tracing the Evolution of a Contested Concept." Journal of Social Policy; Cambridge, 45, 635-653

Baskerville, Rachel. (2003). Hofstede Never Studied Culture. Accounting, Organizations and Society. 28. 1-14. 10.1016/S0361-3682(01)00048-4

Beges, S., Buckner, E., and Khatib, L. (2012) Social Entrepreneurship: Why Is It Important Post Arab Spring? Stanford University Program on Arab Reform and Democracy. Retrieved from http://iisdb.stanford.edu/pubs/23656/White_Paper_Social_Entrepreneurship.pdf.

Bhatt, E. (2006). We are Poor but So Many: The Story of Self-employed Women in India. New Delhi: Oxford University Press

Burntley, S.J. (2007). A review of municipal solid waste composition in the United Kingdom. Journal of Waste Management 27 (10), 1274-1285

CAPMAS. (2019). Egypt in Figures 2018. Central Agency for Public Mobilization and Statistics (CAPMAS), Cairo, Egypt. Retrieved from http://www.capmas.gov.eg/Pages/GIS_Boundaries. aspx?page_id=5074

Carr, S. and Lynch, K., (1981). Open space: Freedom and control. Urban open spaces, pp.17-18

Denis, E, \& Séjourné, M. (2002). ISIS: Information system for informatsett

Denis, E., \& Séjourné, M. (2002). ISIS: Information system for informal settlements.

Dimitrijević, B. (2019). Agile urban planning and phased høusing construction for migrating populations. In M. Mihajlovic (Ed.), Environmental Impact of Illegal Construction, Poor Planning and Design: IMPEDE 2019, Belgrade, pp. 25-35

Dokko, G. \& Wilk, S. \& Rothbard, N. (2009). Unpacking Prior Experience: How Career History Affects Job Performance. Organization Science. 20. 51-68. 10.1287/orsc.1080.0357

El-Batran, M. and Arandel, C. (1998). A shelter of their own: informal settlement expansion in Greater Cairo and government responses. Environment and Urbanization, 10 (1), pp.217-232

El-Defrawi, S., (2013). Impact of physical structure of informal settlements on the social integration of residents. In Berlin: International RC21 Conference (pp. 1-11). Retrieved from https://elnidaa.org/app/uploads/2019/07/ENID_achievement report.pdf

El-Ebrashi, R. (2013).Alashanek ya Balady: Defining Social Entrepreneurship. The American University in Cairo. Retrieved from http:/ www.aucegypt.edu/Business/kcc/Documents/Alashanek\%20Ya\%20Balady.pdf

Flick, U. (2007). Qualitative Research kit: Managing quality in qualitative research. London : SAGE Publications, Ltd doi: $10.4135 / 9781849209441$

$$
1>1
$$

Gaddefors, J. \& Anderson, A. (2017). Entrepreneursheep and context: when entrepreneurship is greater than entrepreneurs. International Journal of Entrepreneurial Behavior \& Research.23. 267-278. 10.1108/IJEBR-01-20160040

Gianotti, F. (2018). The World in 2019. The Economist Newspaper Limited, p.127

Guérin, I., Marius-Gnanou, K., Pairault, T. et Servet, J-M. (éd.) (2005). Microfinance en Asie:entre traditions et innovations, Paris/Pondichéry, Karthala/IRD/IFP. 
Hattab, H. (2013). GEM Egypt 2012 Report. GEM—Global Entrepreneurship Monitor. Retrieved form http://www.gemconsortium.org/docs/3005/gem-egypt-2012-report

HISS- High Institute for Social Services. (1989). "Towards a Developing Module to Face the Urban Poor Communities Needs in Giza City, Egypt", in the First Technical Conference Integrated Development for Urban Poor Communities, League of Arab States, Cairo

Hollands, R. G. (2015) . Critical interventions into the corporate smart city. Cambridge Journal of Regions, Economy and Society, 8(1), pp.61-77. https://doi.org/10.1093/cjres/rsu011

Horgan, D. and Dimitrijević, B. (2018). Social innovation systems for building resilient communities. Urban Science, 2(1), p.13. DOI: https://doi.org/10.3390/urbansci2010013

Horgan, D. (2020). Placemaking. In: Kobayashi, A. (Ed.), International Encyclopaedia of Human Geography, 2nd edition. vol. 10, Elsevier, pp.145-152. DOI: https://dx.doi.org/10.1016/B978- 0-08-102295-5.10680-8

Horgan, D. and Dimitrijević, B. (2019). Frameworks for citizens participation in planning: From conversational to smart tools. Sustainable Cities and Society, 48, p.101550. DOI: $\quad$ https://doi.org/10.1016/j.scs.2019.101550

Horgan D, Dimitrijević B. Social Innovation in the Built Environment: The Challenges Presented by the Politics of Space. Urban Science. 2021; 5(1):1.

Huber, I. (2018). "Reflections on the Ripple Effects of integrating Gender in Water Management Interventions: the case of Egypt". Presented at the Symposium on Women and Water Security for Peace building in the Arab Region Beirut, 910 May 2018. UN - ESCWA / UNDESA, Pacific Water research centre

ISDF - Informal Settlement Development Facility. (2016). Cairo slum areas. Retrieved from http://www.isdf.gov.eg Khalifa, M.A. (2011). Redefining slums in Egypt: Unplanned versus unsafe areas. Habitat International, 35(1), 40-49

Khalifa, M.A. (2015). Evolution of informal settlements upgrading strategies in Egypt: From negligence to participatory development. Ain Shams Engineering Journal, 6(4), pp.11511159

Khalil, H. E. (2010). New Urbanism, Smart Growth and Informal Areas: A Quest For Sustainability. Sustainable Architecture \& Urban Development, pp.137-156.

Khalil, H., Ibrahim, A., El-Gendy, N., and Makhlouf, N. (2018). Could/should Improving the Urban Climate in Informal Areas of Fast Growing Cities be an Integral Part of Upgrading Processes? Case study, Cairo, Urban Climate, 24, pp. 6379. https://doi.org/10.1016/j.uclim.2018.01.007

Khalil, H., Gammaz, S. (2019). Supporting Informal Areas Resilience: Reinforcing Hidden Green Potentials for a Better Quality of Life, Ecocity World Summit 2019, Vancouver, Canada.

Kitchin, R. (2015). Making sense of smart cities: addressing present shortcomings. Cambridge Journal of Regions, Economy and Society, 8(1), pp. 131-136. DOI: https://doi.org/10.1093/cjres/rsu027.

Lefebvre, H. (1991 [1974]). The Production of Space. Blackwell, Oxford

Lefebvre, H. (1996 [1968]). Writing on Cities. London, Blackwell

Lenette, C and Boddy, C. (2013). "Visual ethnography and refugee women: nuanced understandings of lived experiences", Qualitative Research Journal, Vol. 13 Iss $1 \quad$ pp. $72-89$

Malmendier, U., \& Nagel, S. (2011). Depression Babies: Do Macroeconomic Experiences Affect Risk Taking? The Quarterly Journal of Economics, 126(1), 373-416. Retrieved April 22, 2020, from www.Jstor.Org/Stable/23015670 
Mathias, B., Williams, D, Smith, A (2015) Entrepreneurial inception: The role of imprinting in entrepreneurial action, Journal of Business Venturing, Volume 30, Issue 1, 2015, Pages 11-28,

Mitchell, R.K. , Busenitz, L. , Lant, T. , McDougall, P.P. , Morse, E.A. , \& Smith, B. (2002). Toward a theory of entrepreneurial cognition: Rethinking the people side of entrepreneurship research. Entrepreneurship Theory and Practice, 27(2), 93-104

Moulaert, F. and MacCallum, D. (2019). Advanced Introduction to Social Innovation. Edward Elgar Publishing Mulgan, G., 2019. Social Innovation: How Societies Find the Power to Change. Bristol: Bristol University Press. DOI: https://doi.org/10.2307/j.ctvs89dd3

Munoz, Pablo \& Cohen, Boyd. (2016). The Making of the Urban Entrepreneur. California Management Review. 59. 7191. 10.1177/0008125616683953

Nasrullah, A. \& Dickson, K. (2011). Empowerment of Rural Women, Decent Employment and Micro Enterprise Development Programs of NGOs in Bangladesh. International Journal of Afro-Asian Studies. Vol. 2(2), Brown Walker, USA

Nicolopoulou, K., Lucas, I., Tatli, A., Karatas-Ozkan, M., Costanzo, L., Ozbilgin, M. and Manville, G. (2014). Questioning the Legitimacy of Social Enterprises through Gramscian and Bourdieusian perspectiyes: the case of British Social Enterprises. Journal of Social Entrepreneurship, 6:2, p161-185.

Pink, S. (2006). 'New Sensations? Visual Anthropology and the Senses', The Future of Visual Anthropology: Engaging the Senses, pp. 41-58. London: Routledge Tailor \& Francis Group.

Pink, S. (2012) 'Advances in Visual Methodology: An Introduction', Advances in Visual Methodology, pp. 3-17. London: SAGE Publications.

Rose, G. (1993). Progress in geography and gender. Or something else. Progress in Human Geography, 17(4), 531537. https://doi.org/10.1177/030913259301700407

Salama, A. M. (2011). Trans-disciplinary knowledge for affordable housing, Open House International, 36(3), 7-15

Salama, A. M. \& Wiedmann, F. (2013). Demystifying Doha: on architecture and urbanism in an emerging city. London, Routledge

Salama, A. M., Wiedmann, F., Thierstein, A., \& AL Ghatam, W. (2016). Knowledge economy as an initiator of sustainable urbanism in emerging metropolises: the case of Doha, Qatar, ArchNet-IJAR: International Journal of Architectural Research, $\quad 10(1), 274-324$

Salama, A. M. (2019). Integrationist triadic agendas for city research: cases from recent urban studies. Journal of Architecture and Urbanism, 43(2), 148-157. ～https://doi.org/10.3846/jau.2019.11220

Salama, A. M., \& Grierson, D. (2019). Urban performance between the imagined, the measured, and the experienced. Open House International, 44(1), 4-7

Saunders, M., Lewis, P. and Thornhill, A. (2009), Research Methods for Business Students, Pearson Education, London Shane, S. (1994). Cultural Values and the Championing Process. Entrepreneurship Theory and Practice, 18(4), 2541. https://doi.org/10.1177/104225879401800402

Social Innovation. (2020). Defining Social Innovation. Stanford Graduate School of Business. Retrieved 20 March 2020, from https://www.gsb.stanford.edu/faculty research/centers initiatives/csi/defining-social-innovation 
Steyaert, C. (2004). "The prosaics of entrepreneurship". In Narrative and Discursive Approaches in Entrepreneurship, Edited by: Hjorth, D. and Steyaert, C. 8 21. Cheltenham: Edward Elgar

Sustainable Development Goals | UNDP. (2020). Retrieved 30 March 2020, from https://www.undp.org/content/undp/en/home/sustainable-development-goals.html

Sutton, K., \& Fahmi, W. (2001). Cairo's urban growth and strategic master plans in the light of Egypt's 1996 population census results. Cities, 18(3), 135-149

Welter, F. (2011). Contextualising entrepreneurship, conceptual challenges and ways forward. Entrepreneurship theory and practice, 34 (1), 165-184. doi:10.1111/j.15406520.2010.00427

Westley, F. (2008). The social innovation dynamic. Frances Westley, SiG@ Waterloo.

Winskel, M. (2018) The pursuit of interdisciplinary whole systems energy research: insights from the UK energy research centre, Energy research \& social science, 37 (74-84) 


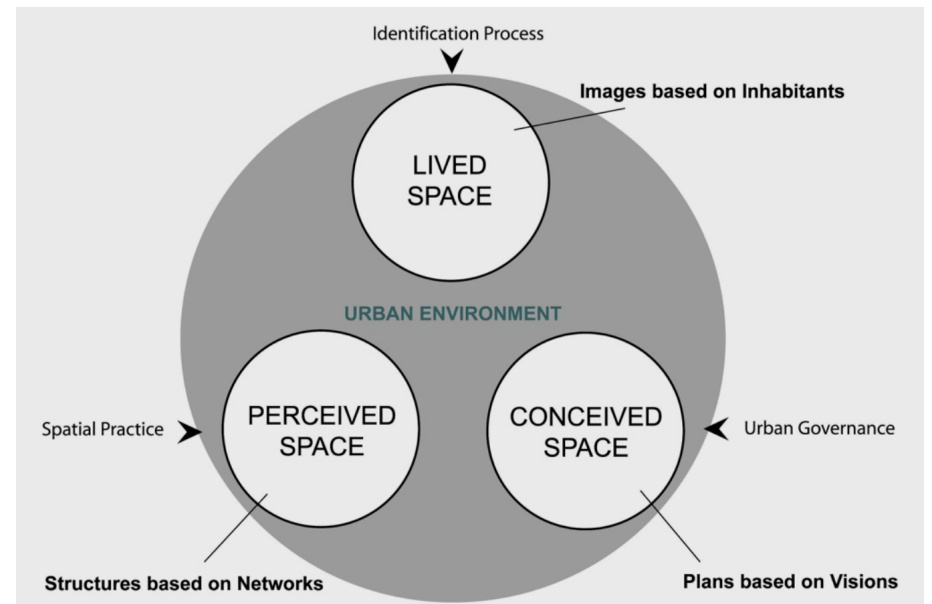

Figure 1- A framework for investigating the production of the urban environment following Lefebvre's Triad (Salama and Wiedmann, 2013)

Figure 2 -Analytical approach following Creswell (2003)
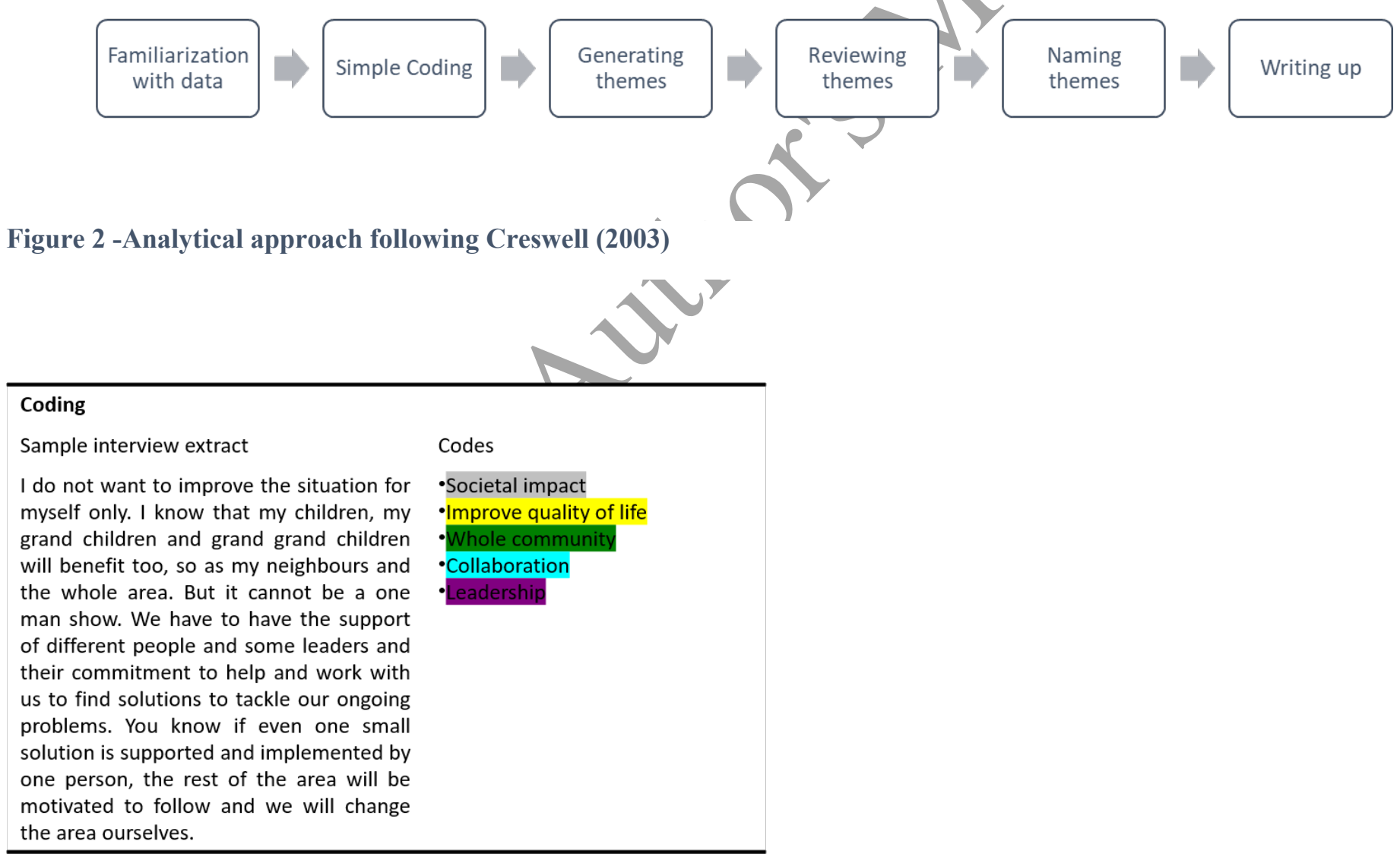

Figure 3 - Sample coding 


\begin{tabular}{ll}
\hline Turning our codes into themes & \\
Codes & Theme \\
•Whole community & Societal impact \\
• Communal collaboration & \\
-Stakeholder collaboration & \\
•Improving community & Social Innovation \\
• Out of the box & \\
-Innovative ideas & \\
-Alternative solutions & \\
-Community solutions & Entrepreneurial support \\
• Understanding legalities & \\
•Need for training & \\
•Entrepreneurial activities
\end{tabular}

Figure 4 - Sample clustering codes

IMAGE 1: Water challenges in unplanned areas in Greater Cairo (Samy Habib, 2019) 

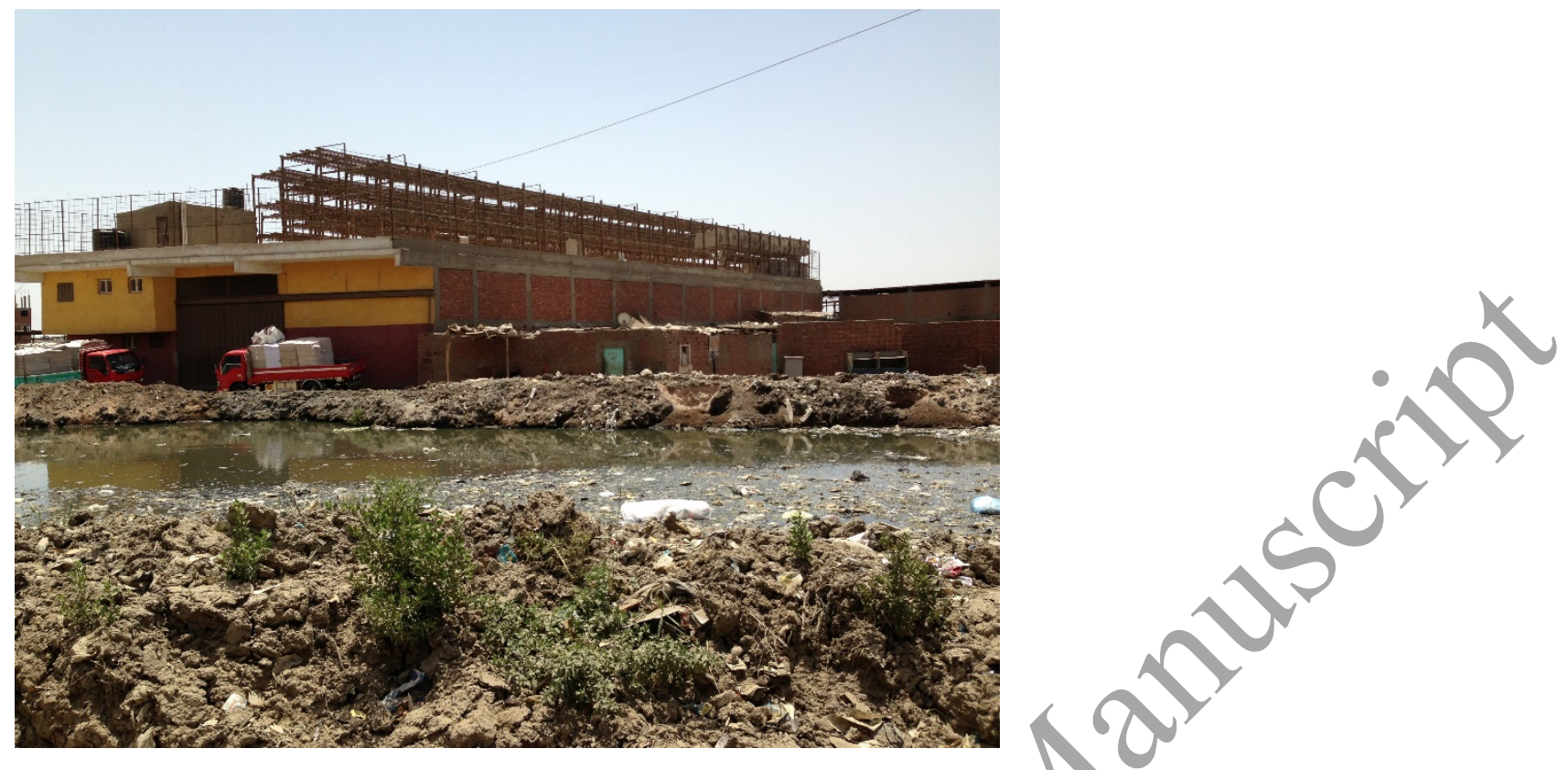

IMAGE 2: Negative sanitation systems - untreated sewage canal in a village on the borders of GCA (Samy Habib, 2019)

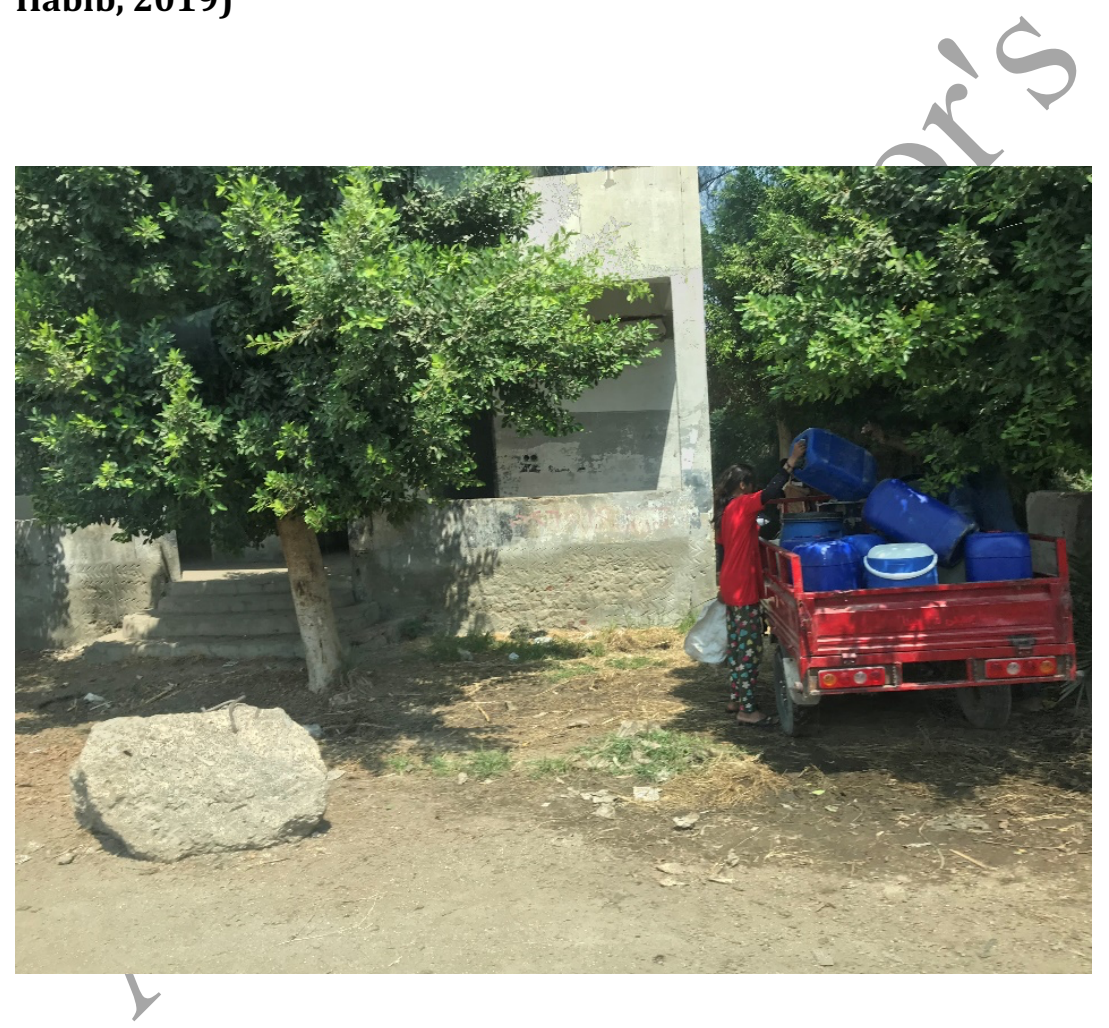

IMAGE 3: A girl helping in delivering drinking water in blue barrels (Samy Habib, 2019) 
TABLE 1: CATEGORIES AND KEY QUALITIES OF UNPLANNED AREAS IN EGYPT

\begin{tabular}{|c|c|c|c|}
\hline Site/category & Example/case & $\begin{array}{l}\text { Socio-Economic } \\
\text { Conditions (and Political Decisions) that led to } \\
\text { their development }\end{array}$ & Key Physical Qualities and Social Qualities \\
\hline $\begin{array}{l}\text { Squatter settlement } \\
\text { developed on government/ } \\
\text { public land. }\end{array}$ & Ezzbat Al Haganna & $\begin{array}{l}\text { - The announcement of official planning schemes gave an } \\
\text { opportunity for the poor to occupy areas near these } \\
\text { schemes to be close to new job opportunities. (Temporary } \\
\text { sites to settle workers near Nasr City, ring road) } \\
\text {-an alternative for who cannot afford agricultural land, they } \\
\text { build on desert state owned lands or buy it illegally from } \\
\text { local brokers }\end{array}$ & $\begin{array}{l}\text { - Spatial characteristics like walkability, self-sufficiency, convenience and } \\
\text { home/work proximity, safety in residential streets and participation in } \\
\text { provision of public amenities. } \\
\text { - The social coherence of the communities in the informal areas has } \\
\text { great potential; marginalized communities are forced to create closely } \\
\text { connected social networks. } \\
\text { - Compact Urban forms with mixed use of residential and commercial } \\
\text { uses that benefit the settlements; walkable, self-sufficient and } \\
\text { convenient for daily needs, home/work proximity and safety. }\end{array}$ \\
\hline $\begin{array}{l}\text { Squatter } \\
\text { settlement developed on } \\
\text { private land }\end{array}$ & \multicolumn{3}{|c|}{ Not Relevant in the Egyptian Context } \\
\hline $\begin{array}{l}\text { Settlement for refugees or } \\
\text { vulnerable communities/ } \\
\text { migrants }\end{array}$ & \multicolumn{3}{|c|}{$\begin{array}{l}\text { Not Relevant in the Egyptian Context } \\
\text { The migrants of the } 1970 \text { s are now integrated in the communities }\end{array}$} \\
\hline $\begin{array}{l}\text { Informal areas that were } \\
\text { upgraded, but fell into a } \\
\text { new cycle of deterioration }\end{array}$ & \multicolumn{3}{|c|}{ Not Relevant in the Egyptian Context } \\
\hline $\begin{array}{l}\text { Illegal sub-urban land } \\
\text { subdivision on legally } \\
\text { owned land. }\end{array}$ & $\begin{array}{l}\text { Imbabah Cairo (on } \\
\text { agricultural land) }\end{array}$ & $\begin{array}{l}\text { Rapid urban development grew in an informal unplanned } \\
\text { pattern, housing displaced people from rural areas, } \\
\text { especially Upper Egypt because in uncertain times buying } \\
\text { land is much safer investment; due to Egyptian inheritance } \\
\text { laws the land shares are divided equally between children } \\
\text { and can lay around idle till disputes are settled or childless } \\
\text { siblings arrange the Ministry or Awqaf }\end{array}$ & $\begin{array}{l}\text { - The same characteristics as the settlements on desert land, but } \\
\text { differences in having a higher tenure security and the inhabitants are of } \\
\text { wider socio-economic spectrum. }\end{array}$ \\
\hline $\begin{array}{l}\text { overcrowded } \\
\text { derelict legal social } \\
\text { housing that became } \\
\text { informal. }\end{array}$ & $\begin{array}{l}\text { Al Zelzal housing in New } \\
\text { Cairo }\end{array}$ & $\begin{array}{l}\text { - Failure to understand the importance of the location, the } \\
\text { importance of reciprocity in conditions of low-income and } \\
\text { informal economies as well as the importance of social } \\
\text { networks }\end{array}$ & \\
\hline $\begin{array}{l}\text { Historic environments that } \\
\text { were gradually } \\
\text { deteriorated and became } \\
\text { informal. }\end{array}$ & $\begin{array}{l}\text { Parts of old Cairo such as } \\
\text { Darb Al Ahmar }\end{array}$ & & \\
\hline $\begin{array}{l}\text { Category not included in } \\
\text { the typology: settlements } \\
\text { in Cemeteries }\end{array}$ & City of the Dead Cairo & $\begin{array}{l}\text { - Guards are employed to take care of graves, and over time } \\
\text { they settle there with their family, children and } \\
\text { grandchildren. It is the destination for the poorest } \\
\text { immigrants. }\end{array}$ & \\
\hline
\end{tabular}


TABLE 2: CHALLENGES OF UNPLANNED AREAS AND PROPOSED STRATEGIES

\begin{tabular}{|c|c|c|c|c|}
\hline Site/category & $\begin{array}{l}\text { Key Challenges (Water } \\
\text { and others) }\end{array}$ & $\begin{array}{l}\text { Main identified water } \\
\text { challenges }\end{array}$ & Intervention Strategies & $\begin{array}{l}\text { Aspiring proposed actions for } \\
\text { entrepreneurship and innovation }\end{array}$ \\
\hline $\begin{array}{l}\text { Squatter settlement } \\
\text { developed on government/ } \\
\text { public land. }\end{array}$ & $\begin{array}{l}\text { Lack of facilities, amenities } \\
\text { and infrastructure } \\
\text { Most have electricity, but } \\
\text { water and sanitation vary } \\
\text { from one area to another }\end{array}$ & $\begin{array}{l}\text { Weak water infrastructure; } \\
\text { some settlements do not have water } \\
\text { in houses }\end{array}$ & $\begin{array}{l}\text { The current strategy the country applies is relocation } \\
\text { and redevelopment. People are relocated either } \\
\text { temporarily while redeveloping the area, or } \\
\text { permanently to public houses which are poorly located } \\
\text { with no available jobs and livelihood, not meeting } \\
\text { people's needs }\end{array}$ & $\begin{array}{l}\text { - Water courriers ('just drink'): small fee to transport } \\
\text { water /distribute to communities (business } \\
\text { opportunity) } \\
\text { - Set up self help child care to facilitate the process of } \\
\text { enterprising in water } \\
\text { - Water tank for intermittent supply (between } \\
\text { communities)- use similar best cases from Africa } \\
\text { - Implement simple testing kits to identify problems } \\
\text { - Use textile/knitting skills to create water filters }\end{array}$ \\
\hline $\begin{array}{l}\text { Illegal sub-urban land } \\
\text { subdivision on legally } \\
\text { owned land. }\end{array}$ & $\begin{array}{l}\text { The settlements on private } \\
\text { land tend to be of higher } \\
\text { quality than squatter } \\
\text { settlements on the public } \\
\text { land }\end{array}$ & $\begin{array}{l}\text { Agricultural lands are more easily } \\
\text { illegally connected to any public } \\
\text { networks, especially to already } \\
\text { existing water connection points }\end{array}$ & $\begin{array}{l}\text { The current strategy the country applies is relocation } \\
\text { and redevelopment. People are relocated either } \\
\text { temporarily while redeveloping the area, or } \\
\text { permanently to public houses which are poorly located } \\
\text { with no available jobs and livelihood, not meeting } \\
\text { people's needs }\end{array}$ & $\begin{array}{l}\text { - Capacity building in specific trades or schemes } \\
\text { - Water point committees and the development of } \\
\text { partnerships with established institutional } \\
\text { stakeholders like NGOs and Banks } \\
\text { - Introduce digital (e-payments) to boost savings and } \\
\text { safeguard funds/sales } \\
\text { - Product differentiation (clean bottled water- different } \\
\text { colour per village) to prove purity led by women } \\
\text { - Community groups to share water saving ideas and } \\
\text { good practice } \\
\text { - Explore the set up of water user associations } \\
\text { - Raise awareness about global dimensions of the } \\
\text { problem and highlight set of barriers }\end{array}$ \\
\hline $\begin{array}{l}\text { overcrowded } \\
\text { derelict legal social } \\
\text { housing that became } \\
\text { informal. }\end{array}$ & $\begin{array}{l}\text { The deterioration of the } \\
\text { houses and most of social } \\
\text { houses are built in the } \\
\text { periphery far from jobs and } \\
\text { does not have the same } \\
\text { qualities of compact urban } \\
\text { fabric }\end{array}$ & Weak water infrastructure & & $\begin{array}{l}\text { - Permaculture } \\
\text { - Help develop smartphone apps to connect and share } \\
\text { and reporting GPS } \\
\text { - Create a thread impregnated with water purifiers }\end{array}$ \\
\hline $\begin{array}{l}\text { Historic environments that } \\
\text { were gradually } \\
\text { deteriorated and became } \\
\text { informal. }\end{array}$ & $\begin{array}{l}\text { Parts of old Cairo such as } \\
\text { Darb Al Ahmar }\end{array}$ & & & $\begin{array}{l}\text { - The housing stock deteriorated overtime as mostly its } \\
\text { rent value has been frozen at } 1944 \text { rent values }\end{array}$ \\
\hline
\end{tabular}

